\title{
FLORISTIC BIODIVERSITY OF WEED COMMUNITIES IN ARABLE LANDS OF ISTRIA PENINSULA (FROM 2005 TO 2017)
}

\author{
EDITA ŠTEFANIĆ ${ }^{1}$, VESNA KOVAČEVIĆ ${ }^{2}$, SLAVICA ANTUNOVIĆ ${ }^{3}$, BOŽICA \\ JAPUNDŽIĆ-PALENKIĆ ${ }^{3}$, DINKO ZIMA ${ }^{4}$, ALKA TURALIJA ${ }^{5}$, NIKOLA NESTOROVIĆ ${ }^{6}$
}

${ }^{1}$ Department of Plant Protection, J.J. Strossmayer University in Osijek, Faculty of Agriculture, V. Preloga 1, 31000

Osijek, Croatia, e-mail: estefanic@pfos.hr

${ }^{2}$ Polytechnic in Rijeka, K. Huguesa 52, 44000 Poreč, Croatia; e-mail: vesna.kovacevic@veleri.hr ${ }^{2}$

${ }^{3}$ College of Slavonski Brod, Dr. M. Budaka1, 35000 Slavonski Brod, Croatia; e-mail: santunovic@vusb.hr

${ }^{4}$ Polytechnic in Požega, Vukovarska 17, 34000 Požega, Croatia; e-mail: dzima@vup.hr

${ }^{5}$ Department of Crop Science, J.J. Strossmayer University in Osijek, Faculty of Agriculture, V. Preloga 1, 31000 Osijek, Croatia; e-mail: alka.turalija@pfos.hr

${ }^{6}$ Student, J.J. Strossmayer University in Osijek, Faculty of Agriculture, V. Preloga 1, 31000 Osijek, Croatia; e-mail: nnestorovic@pfos.hr

\begin{abstract}
Štefanić E., Kovačević V., Antunović S., Japundžić-Palenkić B., Zima D., Turalija A., Nestorović N.: Floristic biodiversity of weed communities in arable lands of Istria peninsula (from 2005 to 2017). Ekológia (Bratislava), Vol. 38, No. 2, p. 166-177, 2019.

This paper analyses the floristic biodiversity of weed communities in the arable lands of the Istrian peninsula during a twelve year period (2005-2017). A total of 50 fields were surveyed for each sampling time using the seven-degree Braun-Blanquet cover abundance scale in the following agricultural categories: a) permanent crops (vineyards/olive groves), b) alfalfa fields, c) cereals, d) row crops and e) ruderal areas. The taxonomic identification was performed during the full development of vegetation, for cereals in June and July, and for the rest - in August and September. A total of 175 weed species were determined during both study periods with Asteraceae and Poaceae families as the most abundant. Altogether, therophytes were dominant in both surveys, followed by hemycryptophytes and geophytes. Variations in species composition were visible in both study periods (2005 and 2017) as well as in the selected habitat types. Exclusive species were found in addition to those that were common for both surveys. Changes in species composition between 2005 and 2017 referred to the difference in row spacing in earlier period, and ruderal vs. agricultural habitats in the recent survey. The differences in phenological traits between the past and present surveys were greatest for germination season in permanent crops and row crops, flowering start for permanent crops, flowering period for ruderal area and weed height for permanent crops. Significant differences between the past and present survey for other plant traits did not occur.
\end{abstract}

Key words: weeds, species shifts, relative change, troublesome index, weed functional traits.

\section{Introduction}

Arable weed vegetation represent a very dynamic and widespread system, but its biodiversity has been progressively changing in many agricultural areas worldwide (Rotches- 
Ribalta et al., 2015, Chamorro et al., 2016, Burda, 2018). Since weeds pose a major threat to successful crop production, a lot of efforts have been carried out in intensification in agriculture during the last decades. Rapid changes in agricultural practices with intensive chemical fertilization and herbicide application, sowing high competitive crops, seed cleaning techniques and so on, had a significant impact on the number and abundance of arable weeds resulting in a huge decline in weed biodiversity (Sutclife, Kay, 2000; Barančok, Barančoková, 2016).

Surveying the flora of arable weeds has been a subject of many researches (Cirujeda et al., 2011., Kolarová et al., 2013) confirming that weeds are now among the most threatened groups of vascular plants (Storkey et al., 2012). A meta-analysis of changes in floristic composition of weed communities across Europe showed on average a $20 \%$ reduction of species per field between 1939 and 2012 (Richner et al., 2015). Several recent studies have been dealing with this problem and often led to contradictory results. For example, Lososová et al. (2004) explain that major changes in weed species composition in the Czech Republic and Slovakia were associated with a complex gradient of increasing altitude and precipitation and decreasing temperature and base status of the soil. Fried et al. (2008) suggested that major variations in species composition between fields were associated with crop type, while Pinke et al. (2010) explained that most of the variation inside the weed community could be explained by the seasonal aspect.

Change in diversity and composition of arable weed communities may also lead to changes in the community plant trait spectrum (Franke et al., 2009, Thompson et al., 1998). Plant traits, instead of species, are actually better adopted to particular specific cropping practices and agricultural habitats, hence, arranging weed species into functional groups may give a better understanding of how weed communities are assembled (Booth, Swanton, 2002).

This study aimed to compare the weed communities surveyed in 2005 and 2017 and to assess if the effect of weed shifting processes is visible in a twelve year period. The objective is to determine quantitative and qualitative relationships between crops and weed communities, and then to test the selected weed traits in the investigated agricultural categories to explore their functional response in a changing context.

\section{Material and methods}

\section{Site description}

Istria is the largest peninsula, situated in the north-west part of the Adriatic Sea, between the Gulf of Trieste and Kvarner Gulf. It spreads over three countries: Italy, Slovenia and Croatia, but the largest portion of the peninsula (89\%) belongs to the Republic of Croatia, between latitude $45^{\circ} 15^{\prime} 24.00^{\prime \prime} \mathrm{N}$ and longitude $13^{\circ} 54^{\prime} 9.59^{\prime \prime}$ E. The basic climate of the Istrian peninsula is Mediterranean. However, along the coast, it gradually changes towards the continent and it passes into continental climate, due to cold air circulating from the mountains and due to the vicinity of the Alps.

Istria has diverse landscapes and can be divided in three completely different areas. The hilly northern and north-eastern part of the peninsula - due to its scarce vegetation and nude Karst surfaces also known as White Istria. South-west from White Istria stretches considerably richer morphologically area. These are the lower flisch mountainous tracts consisting of impermeable marl, clay, and sandstone, which is why this part is called Grey Istria. Limestone terrace along the coastline, covered with red earth is called Red Istria. Agriculture has a long tradition in this territory, and nowadays a great attention is being given to the production of ecologic food, wine and olive growing. 


\section{Data sampling}

A phytosociological relevés at a standard size of $100 \mathrm{~m}^{2}$ surfaces were performed in each study period (2005 and 2017). Relevés were recorded in the centre of the fields to avoid the effect of neighbouring vegetation. A total of 50 fields were randomly selected in the so called 'gray' fertile inner land and 'red' coastal line part of the peninsula in 2005 and 2017, respectively. The fully developed vegetation was sampled as follows: for cereals in June and July, and for row crops, alfalfa, permanent crops and ruderal areas in August and September. All sampling sites shared the same aspect, soil bedrock, and a very similar altitude and slope. They were classified into the following agricultural categories: a) permanent crops (vineyards/olive groves), b) alfalfa fields, c) row crops, d) cereals and e) ruderal habitats.

The species coverage was estimated using the 7-degree Braun-Blanquet cover-abundance scale (Braun-Blanquet, 1964) and then transformed to an ordinal scale (Van Der Maarel, 1979), while their nomenclatural treatment mainly followed the check-list of Flora Croatica Database (https://hirc.botanic.hr/fcd/).

\section{Data analysis}

First, all the raw data were used for community evaluation, including the construction of the Venn diagram to determine the number of species distributed at or exclusive to each type of agricultural category and respective occurrence times. Then, to quantify the shift in weed species composition, a relative change of weed species was calculated using a method employed by Webster, Coble (1997) to compare the weeds surveys from 2005 and 2017 in permanent crops (vineyards/ olive groves), alfalfa fields, row crops, cereals and ruderal habitats. Relative change (RC) for each species were calculated as follows: if a species that was the seventh most troublesome weed in past survey, and third most troublesome weed in recent survey, then the relative change would be +4 . The weed that is not found in one of the surveys was considered to be the $11^{\text {th }}$ most severe weed. The average change (AC) was calculated by dividing the relative change by the number of fields in the survey. Finally, the troublesome weed index (TWI) was calculated for both surveys (2005 and 2017) and consisted of the sum of rankings of weed species in each relevé.

This dataset was then used for multivariate analysis to identify factors (crop type) accounting for most of the variance within vegetation data. For that purpose, canonical discriminant analysis (CDA) was used to evaluate the association between agricultural categories on the occurrence of weed species using CANOCO 5 (ter Braak, Smilauer, 2012).

Finally, weed communities were analysed according to their functional traits. The eleven selected weed traits were obtained from the BiolFlor database (http://www.ufz.de/index.php) and included phenological traits (germination and flowering time and duration of the flowering season), traits relevant to plant competition (Storkey, 2006) like plant height together with Ellenberg indicator values for light, moisture and nutrient preferences (Ellenberg et al., 1992). Raunkiaer life forms was also added (Raunkiaer, 1934). For each agricultural category tested, mean comparisons of the past (2005) and present (2017) survey were made based on the mean selected traits using a two-sample t-test $\left(\mathrm{H}_{0}\right.$ : vegetation in 2005 = vegetation in 2017).

\section{Results}

In total, 175 different weed species belonging to 36 families were found in the study area. In both surveys (2005 and 2017), the most representative families in terms of species richness were Asteraceae, Poaceae and Fabceae (Fig. 1). The domination of the Asteraceae family is particularly visible in 2017, Fabaceae shows a decrease in species richnes, while Poaceae remains stable without significant differences in their incidence throughout the study period.

Therophytes with $47 \%$ in 2005 and 51\% in 2017 were a dominant life form, and the abundance of hemicryptophytes and geophytes were 37 and 11\% in 2005 and 34 and 7\% in 2017, respectively. Regarding the life forms in the selected agricultural categories, a slight increase of therophytes coupled to a reduction of hemicryptophytes occurred from 2005 to 2017 study periods in row crops and cereals (Fig. 2). However, permanent crops (vineyards and olive groves) increase the presence of geophytes in 2017, while the other life forms did not experience any significant variation. 


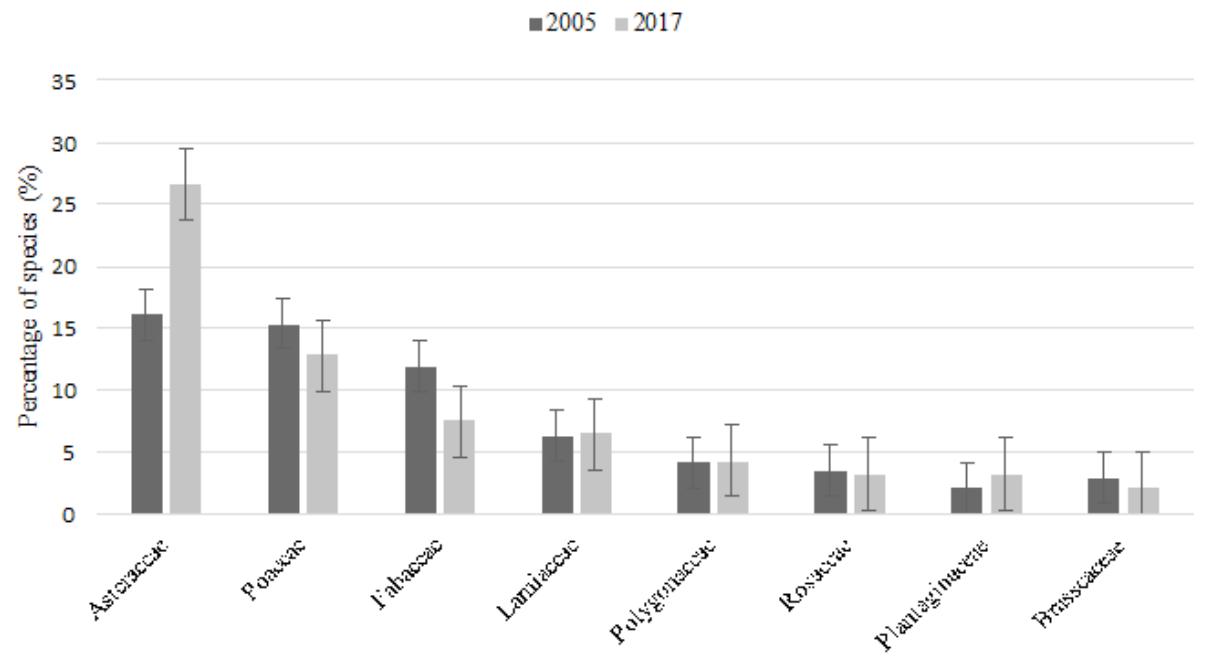

Fig. 1. Percentage of species in the main families of weeds found in the surveys during 2005 and 2017. Vertical bars represent the standard errors of means.

In both study periods (2005 and 2017), exclusive species were found in addition to those that were common to both surveys (Fig. 3). Altogether, there were 176 species found in this study. Richness was higher in 2005 (143 species), than in 2017 (97 species). Species common to both surveys were 64, but in earlier period, there were 79 species differentials that was not found in 2017. However, in the recent survey, 33 new weeds were discovered, which were not found in the 2005 appear.

Variation in weed species composition were also visible in the selected habitat types. For example: the richest ruderal weed community with a total of 99 species significantly decreased in richness from 85 found in 2005 to only 31 weed species in 2017 (Fig. 3). Only 17 species were common to both surveys. The weeds that have significantly declined in importance include Ambrosia artemisiifolia and Lolium multiflorum (Table 1). These two species were ranked as thirteenth and twelfth most troublesome weeds, respectively. Although Avena fatua was reduced 4 places in the relative rating, it was still ranked as the first troublesome weed (Table 1). Beside $A$. fatua, the up-and-coming troublesome weeds are also Convolvulus arvensis and Chenopodium album. These species have the biggest increases during the study period (RC: 11, and 9, respectively) and were ranked as the second and third most troublesome weeds in the ruderal areas (Table 1).

Permanent crops (vineyards and olive groves) were also floristically rich with a total of 86 species recorded throughout the study. The richest community was in 2017 having 66 species, compared to the past survey (2005) with 45 recorded weeds (Fig. 3). Common to both periods were 25 species, but 20 exclusive to the earlier period and 41 exclusive to the recent survey. The highest change happened to Portulaca oleracea, which decreases in its relative importance to the sixteenth place. In spite of this significant decrease in importance, it is still ranked on the sixth 

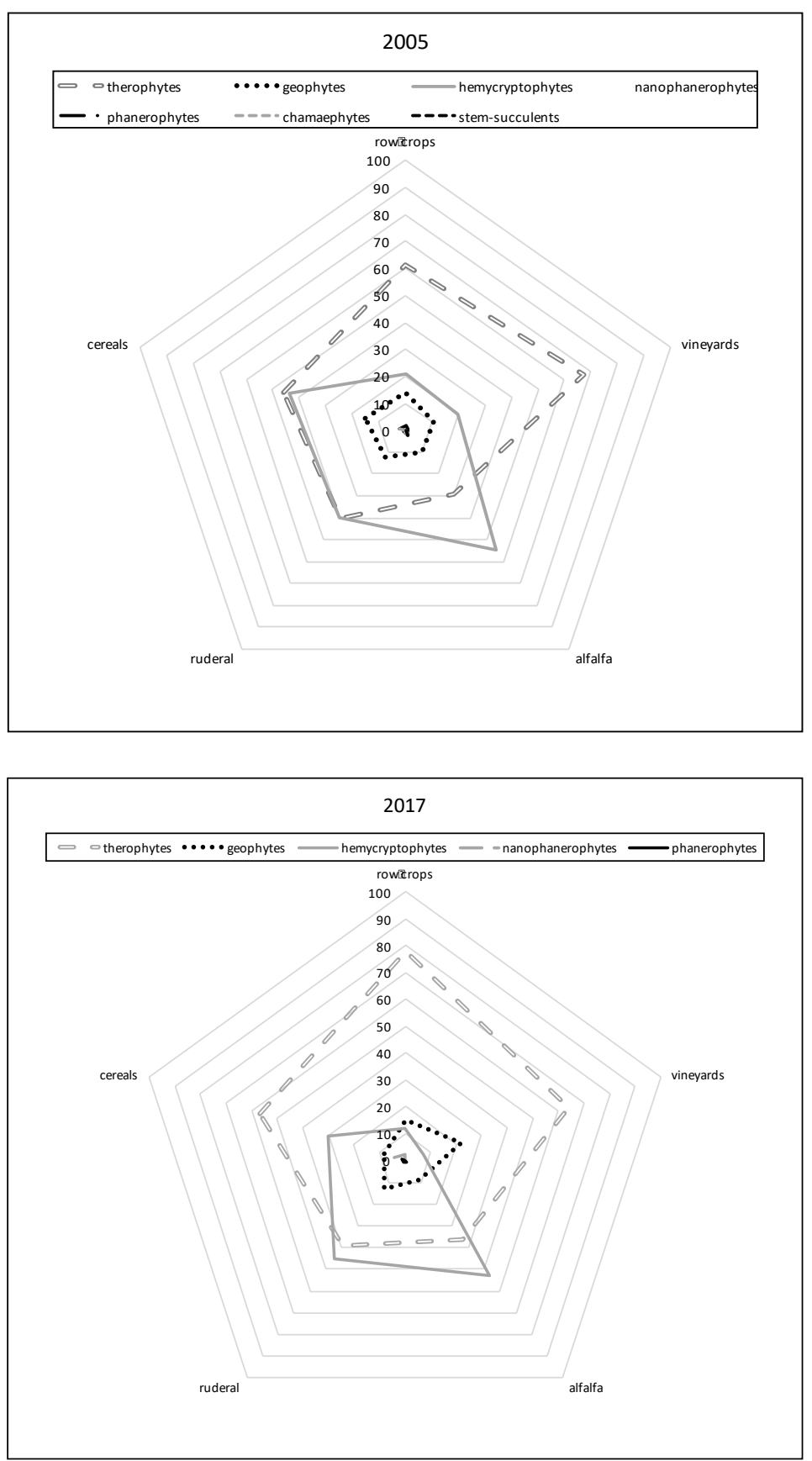

Fig. 2. Percentage of life forms in the investigated agricultural habitats in 2005 and 2017. 

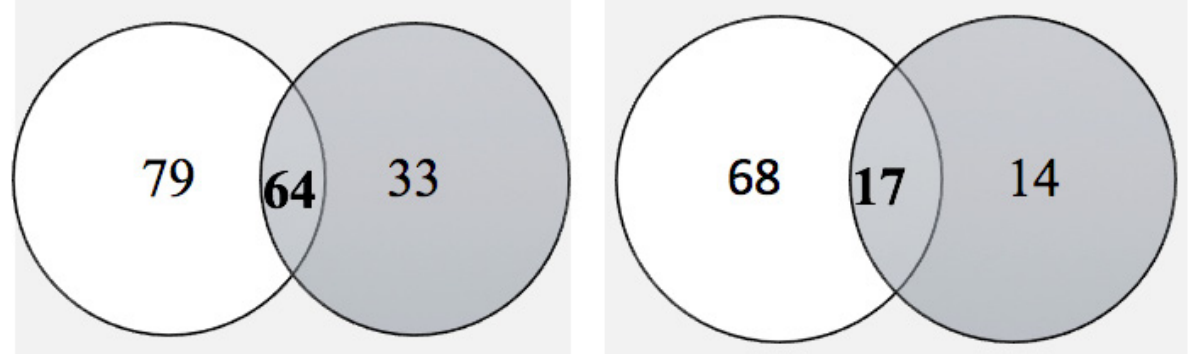

A

B
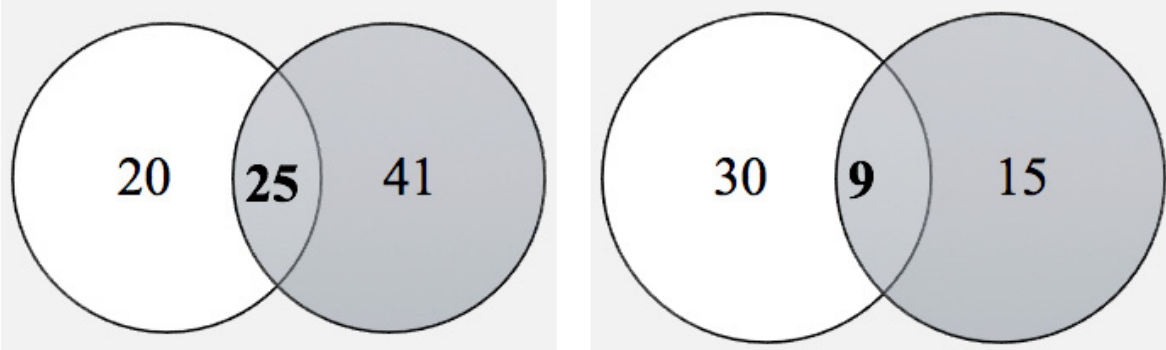

C

D
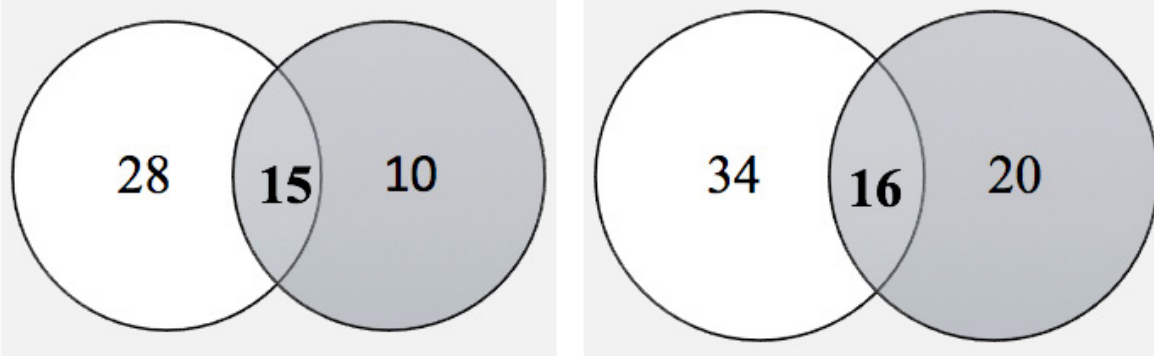

$\mathbf{E}$

F

Fig. 3. Venn diagram with number of species of the weed communities found in 2005 (no fill) and 2017 (grey fill) in A: total area, B: ruderal area, C: permanent corps, D: alfalfa, E: cereals, F: row crops. 


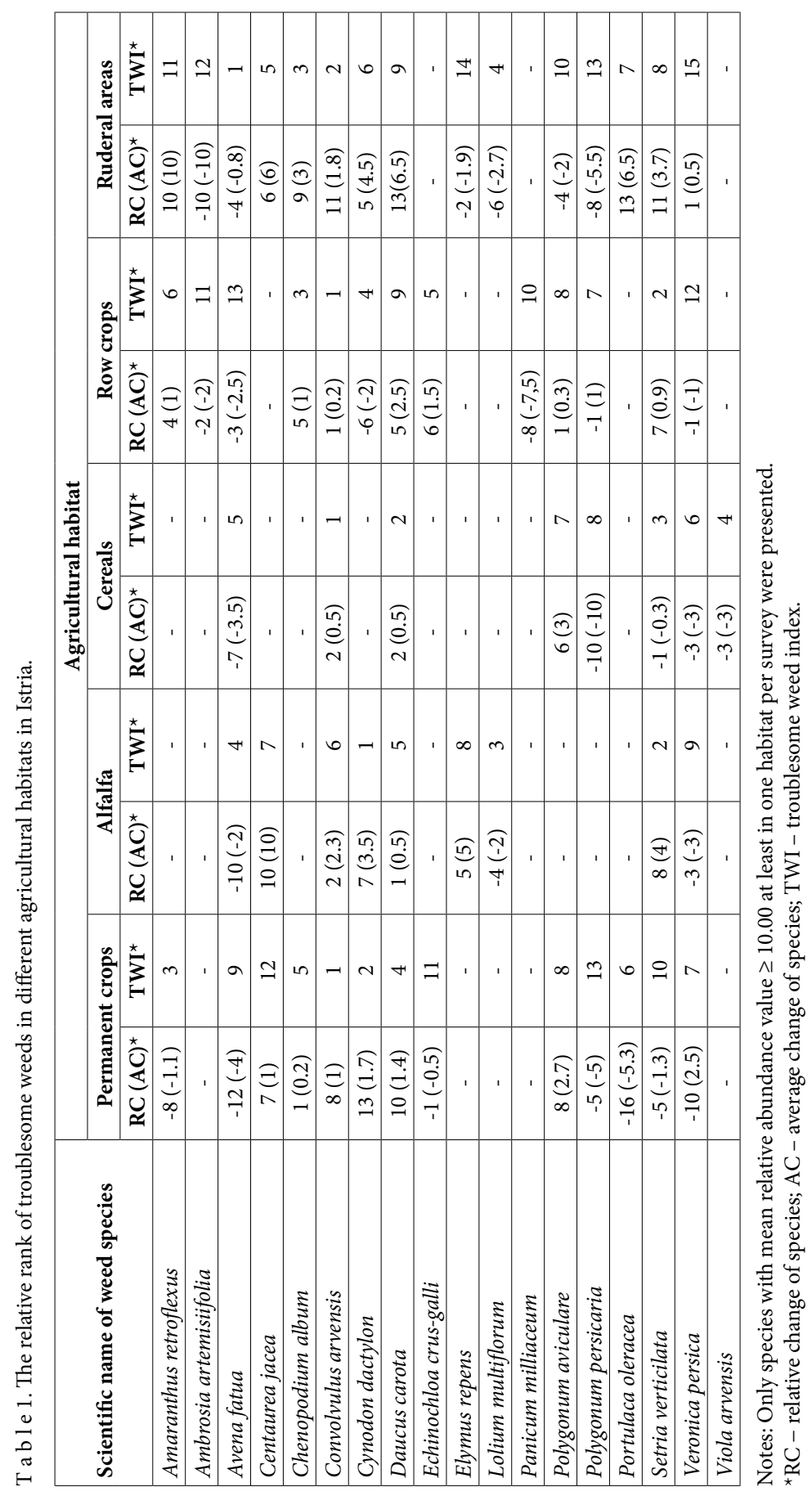


position as troublesome weed in permanent crops. The established troublesome weeds that have increased in importance were Convolvulus arvensis (RC: 8) and Cynodon dactylon (RC: 13) and were ranked on the first and second places as troublesome weeds in permanent crops (Table 1).

Alfalfa was the poorest weed community with a total of 54 determined species in both surveys. Weed community in 2005 comprised of 39 species, however, it significantly decreased in 2017 to 24 species (Fig. 3). There were only 9 species common to both surveys. The biggest increase in the weed ratings were found with C. dactylon and Setaria verticilata (Table 1).

Weed community in cereals comprised of a total of 53 species, having 43 weeds in the past, and 25 in the recent survey. Only 15 were common (Fig. 3). However, the most troublesome weeds Convolvulus arvensis and Daucus carota remain constant in their importance, and were ranked as the first and second most important weeds in cereals (Table 1).

A total of 70 weeds were recorded in row crops during both surveys (Figure 3 ). The number of species decrease from 50 in the past to 36 in the recent survey, and there were 16 species common to both study periods. The most troublesome weeds in row crops during the whole period is Convolvulus arvensis, while Setaria verticilata increased its importance (RC: 7) from the past survey and was ranked on the second place (Table 1). The highest relative change was observed for Panicum milliaceum, which decreased in importance and ranked on the $10^{\text {th }}$ place.

Figures 4 and 5 show the variation in weed species composition in 2005 and 2017, as detected by CCA. Only species with the highest weight are displayed. Based on the ordination diagram in 2005 (Fig. 4), the first axis corresponded to row spacings and explained $27.9 \%$ of the total variation in species data, while the second axis mainly referred to the differences between ruderal vegetation and crops that explained additional $19.3 \%$ of the total variation.

In 2017, the first axis explained $32.1 \%$ of variation and clearly separated agricultural fields from

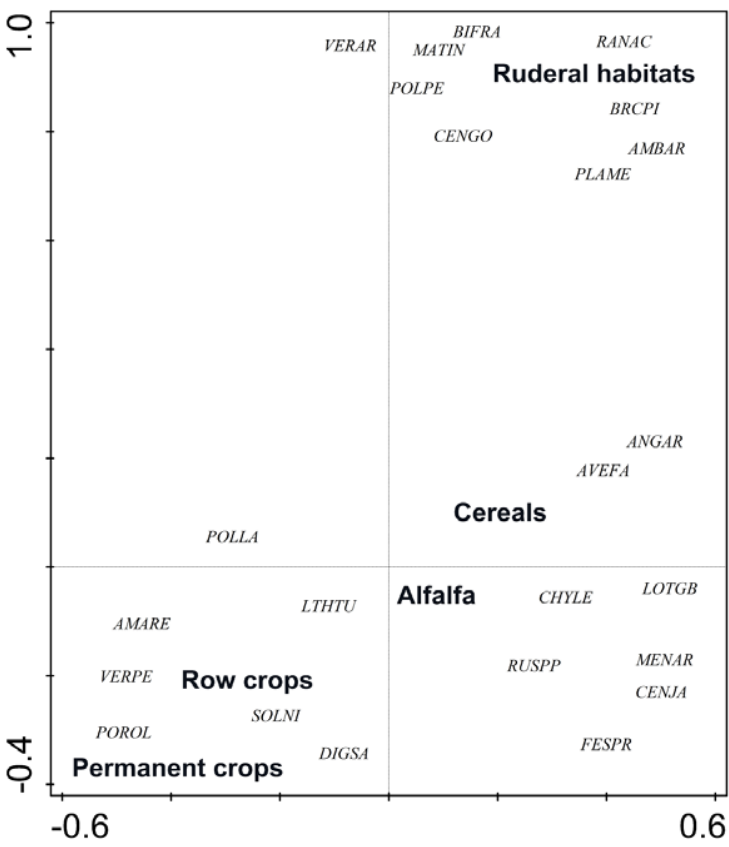

Fig. 4. Two-dimensional CCA ordination diagram of weed species in 2005 with explanatory variables. Species with low weight are not shown.

Notes: AMARE = Amaranthus retroflexus, $\mathrm{AMBAR}=$ Ambrosia artemisiifolia, $\mathrm{ANGAR}=$ Anagalis arvensis, $\mathrm{AVEFA}=$ Avena fatua, $\mathrm{BRCPI}$ = Brachypodium pinnatum, CENJA = Centaurea jacea, DIGSA = Digitaria sanquinalis, LOTGB = Lotus glaber, LTHLU = Lathyrus tuberosus, MENAR = Mercurialis annua, PLAME $=$ Plantago media, POLLA = Polygonum lapathifolium, $\mathrm{POROL}=$ Portulaca oleracea, $\mathrm{RANAC}=$ Ranunculus acris, SOLNI = Solanum nigrum, VERAR = Veronica arvensis, VERPE = Veronica persica. 


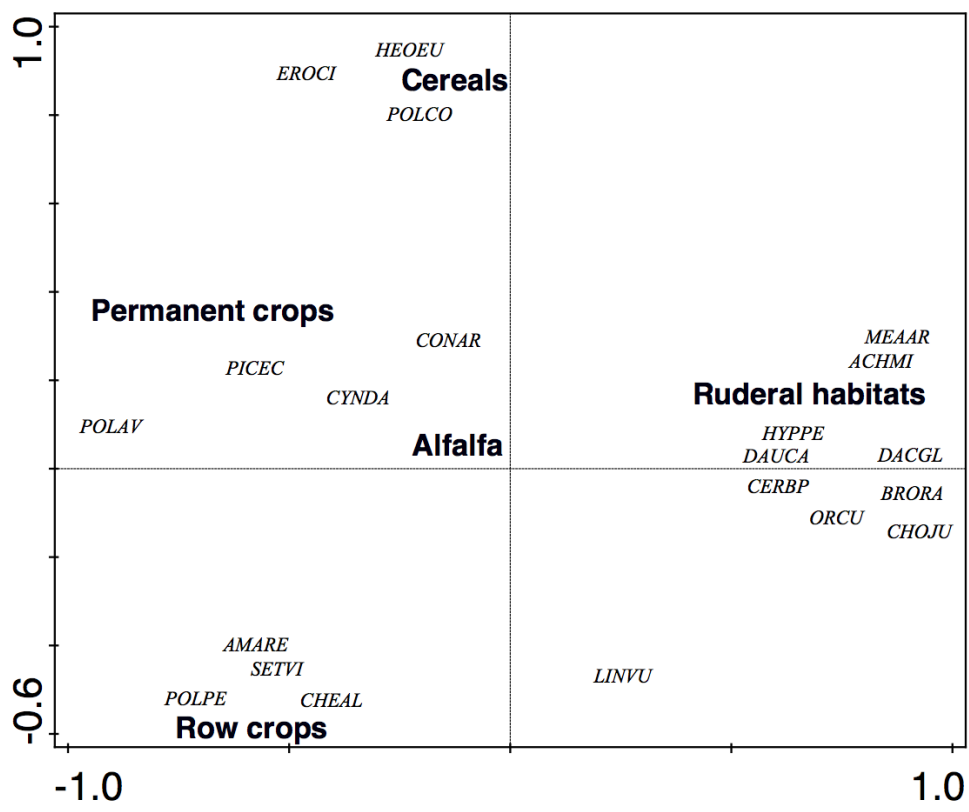

Fig. 5. Two-dimensional CCA ordination diagram of weed species in 2017 with explanatory variables. Species with low weight are not shown.

Notes: $\mathrm{AMARE}=$ Amaranthus retroflexus, $\mathrm{ACHMI}=$ Achillea millefolium, $\mathrm{BRORA}=$ Bromus racemosus, $\mathrm{CARBP}$ = Capsella bursa-pastoris, $\mathrm{CHEAL}=$ Chenopodium album, $\mathrm{CHOJU}=$ Chondrila juncea, $\mathrm{CONAR}=$ Convolvulus arvensis, $\mathrm{CYNDA}=$ Cynodon dactylon, $\mathrm{DACGL}=$ Dactylis glomerata, $\mathrm{DAUCA}=$ Daucus carota, EROCI $=$ Erodium cicutarium, HEOEU = Heliotropium europaeum, HYPPE = Hypericum perforatum, ORCU = Orobanche cumana, PICEC $=$ Picris echioides, POLAV = Polygonum aviculare, POLCO = Falopia convolvulus, POLPE = Polygonum persicaria, SETVI = Setaria viridis.

$\mathrm{T} \mathrm{a} \mathrm{b} 1$ e 2. Differences in trait means of weed communities in arable lands of Istria peninsula between 2005 and 2017 sampling periods.

\begin{tabular}{|l|c|c|c|c|c|c|c|c|c|c|}
\hline \multirow{2}{*}{$\begin{array}{l}\text { Trait means of weed } \\
\text { communities }\end{array}$} & \multicolumn{9}{|c|}{$\begin{array}{c}\text { Agricultural habitats } \\
\text { crops }\end{array}$} & \multicolumn{2}{|c|}{ Alfalfa } & \multicolumn{2}{c|}{ Cereals } & \multicolumn{2}{c|}{ Row crops } & \multicolumn{3}{c|}{$\begin{array}{c}\text { Ruderal } \\
\text { habitats }\end{array}$} \\
\cline { 2 - 12 } & t-stat. & $\mathbf{P}$ & t-stat. & $\mathbf{P}$ & t-stat. & $\mathbf{P}$ & t-stat. & P & t-stat. & P \\
\hline Germination season & -1.976 & $\mathbf{0 . 0 4 4}$ & -0.211 & 0.335 & -1.141 & 0.265 & 0.144 & $\mathbf{0 . 0 4 5}$ & -0.626 & 0.536 \\
\hline Flowering start & -2.828 & $\mathbf{0 . 0 0 7}$ & -0.485 & 0.633 & -0.327 & 0.746 & -0.201 & 0.842 & -0.259 & 0.789 \\
\hline Flowering period & 1.487 & 0.144 & -0.319 & 0.753 & -0.091 & 0.929 & 0.138 & 0.891 & 0.363 & $\mathbf{0 . 0 4 1}$ \\
\hline Height & -2.583 & $\mathbf{0 . 0 1 3}$ & -0.195 & 0.847 & 0.845 & 0.407 & 0.987 & 0.330 & 1.236 & 0.226 \\
\hline Ellenberg moisture & 1.593 & 0.118 & -0.940 & 0.357 & 0.866 & 0.395 & -1.227 & 0.228 & 1.422 & 0.165 \\
\hline Ellenberg light & 0.496 & 0.632 & 0.439 & 0.665 & 0.253 & 0.802 & -0.818 & 0.419 & -0.528 & 0.601 \\
\hline Ellenberg N & 1.914 & 0.062 & -0.238 & 0.814 & 0.401 & 0.692 & -0.818 & 0.419 & -0.320 & 0.751 \\
\hline
\end{tabular}

Notes: Bold type indicates statistical significance ${ }^{*} \mathrm{P}<0.005$ and ${ }^{* *} \mathrm{P}<0.001$. 
ruderal areas (Fig. 5). However, permanent crops and alfalfa were clustered together, whereas row crops and cereals were dispersed along axis 2 , which explained $17.2 \%$ of total variation.

Table 2 shows the associations between investigated agricultural habitats (permanent crops, alfalfa, cereals, row crops and ruderal habitats) and the mean values of weed traits. The differences in paired comparisons between past and present surveys were greatest for germination season in permanent crops and row crops, flowering start for permanent crops, flowering period for ruderal area and weed height for permanent crops. Significant differences between the past and present survey for other plant traits did not occur.

\section{Discussion}

The most abundant families in this study, Asteraceae and Poaceae, were also reported not only as the most representative families in cultivated areas around the globe, but also as the families where many of the world's worst weeds belong and who are capable of producing large quantities of seeds with favourable dispersal mode and capability of colonization in various environments (Holm et al., 1977, 1991).

According to the life-cycle, most of the arable weed species are therophytes and survive as seeds during unfavourable seasons (Sutherland, 2004). After twelve years, the dominance of therophytes in this study became even more prominent, particularly in row crops and cereals, which is certainly the result of a strong anthropogenic impact, that is, an intensification of management practices in crop production (Cirujeda, 2011). Increasing of geophyte in permanent crops is probably related to their adaptation to minimum tillage, which is a widespread technique in this area nowadays (Karoglan Kontić et al., 1999). Moreover, a complex research performed in the Czech Republic and Slovakia indicated not only crops, but altitude, seasonal change and long-term change as the most important variables, which affected life forms and other vegetation characteristics (Lososova et al., 2004). For example, geophyte appears to be more frequent in root crops, therophytes were more common at lower altitudes and in earlier surveys, hemicryptophytes showed opposite patterns.

Weed vegetation, consisting predominantly of annual plants (therophytes), shows a much higher degree of temporal dynamics than other vegetation types (Lososova et al., 2004). Hence, shifts in weed population, and particularly decline of some species and increase in richness and abundance of others, were also detected during this investigation. Such a trend also occurred at field and regional scale in many European countries with intensive agricultural production (Baessler, Klotz, 2006; Richner et al., 2015). Consequences of the agricultural intensification are particularly visible in conventional agriculture leading to a much more rapid decline and loss in biodiversity than in organic agriculture (Flohre et al., 2011; Tilman et al., 2002).

The most troublesome weeds across all agricultural habitats in Istria is perennial vine Convolvulus arvensis, which has been shown to have relatively stable patches over time and crop rotations (Jurado-Exposito et al., 2004). An opposite trend was observed for Avena fatua which reduced in importance and particularly declined in permanent crops (-12 points) and alfalfa (-10 points). It probably happened due to the effectively combined diverse and optimal cultural practices and herbicide use against this annual weed (Harker et al., 2016).

Furthermore, comparing the pattern of the weed species composition between the selected agricultural habitats, a light discontinuity between the two sampling periods was observed. In the 
earlier survey (2005), the most significant influence on species composition occurred between the crop types. This indicates that different ecological conditions for weeds with regard to light conditions could affect floristic composition between wide row crops (permanent crops like orchards, olive grows and row crops) and narrow crops (alfalfa and cerelas) and ruderal habitats (Hallgren et al., 1999). Also, many other studies that cover a long-term period (Hallgren et al., 1999; Lososova et al., 2004) revealed that important changes have occurred in weed communities composition and were associated with a specific crop type. Human management factor was the main factor associated with the results from 2017. It showed that the main factor affecting the weed community composition was division between crops and ruderal area, and the second axis distinguished crop types. These results are in agreement with the study of Fried et al. (2008) indicating that a complex relationship in biotic and abiotic factors and their interactions exist between weed communities.

As a final step, the analyses of weed characteristic as community assembly based on the selection of functional traits revealed some changes between the 2005 and 2017 sampling period. In particular, a strong role of phenological characteristics in explaining the weed community shift was found. The main differences for average trait value between the past and recent survey is of earlier germination season and flowering period, and smaller weed heights for weed community in permanent crops in 2017.

In row crops, weed composition in 2017 consisted of weeds that germinated later in the season, and ruderal habitats consisted of weeds with longer flowering period. This phenological relationships is confirmed by the research done by Crowley (2004) that successful weed normally germinate around the time of the crop sown or flower before it is harvested, as well as timing of the tillage affects weed assemblage (Smith, 2006).

\section{Acknowledgements}

We are grateful to Ivana Borozni for correcting our writing style and grammar mistakes.

\section{References}

Baessler, C. \& Klotz S. (2006). Effect of changes in agricultural land-use on landscape structure and arable weed vegetation over the last 50 years. Agric. Ecosyst. Environ., 115, 43-50. DOI: 10.1016/j.agee.2005.12.007.

Barančok, P. \& Barančoková M. (2016). Historical changes in dispersed kopanitse land type and changes in use of agricultural land on Kysuce region example. Ekológia (Bratislava), 35, 371-391. DOI: 10.1515/eko-2016-0030.

Booth, B.D. \& Swanton C.J. (2002). Assembly theory applied to weed communities. Weed Sci., 50, 2-13. DOI: 10.1614/0043-1745(2002)050[0002:AIATAT]2.0.CO;2.

Braun-Blanquet, J. (1964). Pfnanzensoziologie. Grundzüge der vegetationskunde. Wien, New York: Springer Verlag.

Burda, R. (2018). Alien plant species in the agricultural habitats of Ukraine: diversity and risk assessment. Ekológia (Bratislava), 37, 24-31. DOI: 10.2478/eko-2018-0003.

Chamorro, L., Masalles, R.M. \& Sans F.X. (2016). Arable weed decline in Northeast Spain: Does organic farming recover functional biodiversity? Agric. Ecosyst. Environ., 223, 1-9. DOI: 10.1016/j.agee.2015.11.027.

Cirujeda, A., Aibar, J. \& Zaragoza C. (2011). Remarkable changes of weed species in Spanish cereal fields from 1976 to 2007. Agronomy for Sustainable Development, 31, 675-688. DOI: 10.1007/s13593-011-0030-4

Crawley, M.J. (2004). Timing of disturbance and coexistence in a species-rich ruderal plant community. Ecology, 85, 3277-3288. DOI: 10.1890/03-0804.

Ellenberg, H., Weber, H.E., Düll, R., Wirth, W., Werner, W. \& Paulissen D. (1992). Zeigerwerte von Pflanzen in Mitteleureopa. Scripta Geobotanica, 18, 1-258. 
Flohre, A., Fischer, Ch., Aavik, T., Bengtsson, J., Berendse, F., Bommarco, R., Ceryngier, P., Clement, L.W., Dennis, Ch., Eggers, S., Emmerson, M., Geiger, F., Guerrero, I., HAwro, V., Inchausti, P., Liira, J., Morales, M.B., Onate, J.J., Pärt, T., Weisser, W.W., Winqvist, C., Thies, C. \& Tscharntke T. (2011). Agricultural intensification and biodiversity partitioning in European landscapes comparing plants, carabids, and birds. Ecol. Appl., 21 (5), 1771-1781. DOI: 10.1890/10-0645.1.

Franke, A.C., Lotz, L.A.P., Van Der Burg, W.J. \& Van Overbeek L. (2009). The role of arable weed seeds foragroecosystem functioning. Weed Res., 49, 131-141. DOI: 10.1111/j.1365-3180.2009.00692.

Fried, G., Norton, L.R. \& Reboud X. (2008). Environmental and management factors determining weed species composition and diversity in France. Agric. Ecosyst. Environ., 128, 68-76. DOI: 10.1016/j.agee.2008.05.003.

Hallgren, E., Palmer, M.W. \& Millberg P. (1999). Data diving with cross-validation: an investigation of broad scale gradients in Swedish weed communitied. J. Ecol., 87, 1037-1051. DOI: 10.1046/j.1365-2745.1999.00413.x.

Harker, K.N., O’Donovan, J.T., Turkington, T. K., Blackshaw, R. E., Lupwai, N.Z., Smith, E.G., Johnson, E.N., Pageau, D., Shirtliffe, S.J., Gulden, R.H., Rowsell, J., Hall, L.M. \&Willenborg C.J. (2016).Diverse Rotations and Optimal Cultural Practices Control Wild Oat (Avena fatua). Weed Sci., 64, 170-180. DOI: 10.1614/WS-D-15-00133.1.

Holm, L.G., Plucknett, D.L., Pancho, J.V. \& Herberger J.P. (1977). The World's Worst Weeds: Distribution and biology. Honolulu: The University Press of Hawaii.

Holm, L.G., Pancho, J.V., Verberger, J.P. \& Plucknett D.L. (1991). A geographical atlas of world weeds. Malabar: Krieger Publisher Company.

Jurado-Exposito, M., Lopez-Granados, F., Gonzales-Andujar, J.L. \& Garcia-Torres L. (2004). Spatial and temporal analysis of Convolvulus arvensis L. population over four growing seasons. Eur. J. Agron., 21, 287-296. DOI: 10.1016/j. eja.2003.10.001.

Karoglan Kontić, J., Maletić, E., Kozina, B. \& Mirošević N. (1999). Utjecaj zatravljivanja međurednog prostora na značajke vinove loze. Agric. Conspec. Sci., 64(3), 187-198.

Kolarova, M., Tyšer, L. \& Soukup J. (2013). Diversity of current weed vegetation on arable land in selected areas of the Czech Republic. Plant, Soil and Environment, 59, 208-213. DOI: 10.17221/783/2012-PSE.

Lososová, Z., Chytrý, M., Cimalová, Š., Kropáč, Z., Otýpková, Z., Pyšek, P. \& Tichý L. (2004). Weed vegetation of arable land in Central Europe: Gradients of diversity and species composition. J. Veg. Sci., 15, 415-422. DOI: 10.1111/j.16541103.2004.tb02279.x.

Pinke, Gy., Pál, R. \& Botta-Dukát Z. (2010). Effect of environmental factors on weed species composition of cereal and stubble fields in western Hungary. Central European Journal Biology, 5, 283-292. DOI: 10.2478/s11535-009-0079-0.

Raunkiær, C. (1934). The life-forms of plants and statistical plant geography. Oxford: Oxford University Press.

Richner, N., Holderegger, R., Linder, H.P. \& Walter T. (2015). Reviewing changes in the arable flora of Europe: a meta analysis. Weed Res., 55(1), 1-13. DOI: 10.1111/wre.12123.

Rotches-Ribalta, R., Blanco-Moreno, J., Armengot, L., Jose-Maria, L. \& Sans F.X. (2015). Which conditions determine the presence of rare weeds in arable fields? Agric. Ecosyst. Environ., 203, 55-61. DOI: 10.1016j.agee.2015.01.022.

Smith, R.G. (2006). Timing of tillage is an important filter on the assembly of weed communities. Weed Sci., 54, 705-712. DOI: 10.1614 /WS-05-177R1.1.

Storkey, J. (2006). A functional group approach to the management of UK arable weeds to support biological diversity. Weed Res., 46, 513-522. DOI: 10.1111j.1365-3180.2006.00528.

Storkey, J., Meyer, S., Still, K.S. \& Leuschner C. (2012). The impact of agricultural intensification and land-use change on the European arable flora. Proc. R. Soc. Lond. B Biol. Sci., 279(1732), 1421-1429. DOI: 10.1098/rspb.2011.1686.

Sutcliffe, O.L. \& Kay Q.O.N. (2000). Changes in the arable flora of central southern England since the 1960s. Biol. Conserv., 93, 1-8. DOI: 10.1016S0006-3207(99)00119-6.

Sutherland, S. (2004). What makes a weed a weed: life history traits of native and non indigenous plants in the USA. Oecologia, 141, 24-39. DOI: 10.1007s00442-004-1628.

Teer Braak, C.J.F. \& Smilauer P. (2012). Canoco Reference Manual and User's Guide. Software for Ordination (version 5.0). Wageningen, České Budějovice: Biometris.

Thompson, K., Bakker, J.P., Bekker, R.M. \& Hodgson J.G. (1998). Ecological correlates of seed persistence in soil in the north-west European flora. J. Ecol., 86, 163-169. DOI: 10.1046/j.1365-2745.1998.00240.x.

Tilman, D., Cassman, K. G., Matson, P.A., Naylor, R. \& Polasky S. (2002). Agricultural sustainability and intensive production practices. Nature, 418 (6898), 671-677. DOI: 10.1038/nature01014.

van der Maarel, E. (1979). Transformation of cover-abundance values in phyto- sociology and its effect on community similarity. Vegetatio, 39, 97-114. https://www.jstor.org/stable/20145666.

Webster, T.M. \& Coble H.D. (1997). Changes in the weed species composition of the Southern United States: 1974 to 1995. Weed Technol., 11, 308-317. DOI: 10.1017/S0890037X00043001. 